\title{
SARS-CoV-2 proteins (version 2020.2) in the IUPHAR/BPS Guide to Pharmacology Database
}

\author{
Stephen P.H. Alexander ${ }^{1}$, Jonathan K. Ball ${ }^{1}$ and Theocharis Tsoleridis ${ }^{1}$
}

1. University of Nottingham, UK

\begin{abstract}
CoronavirusesCoronaviruses are large, often spherical, enveloped, single-stranded positive-sense RNA viruses, ranging in size from $80-220 \mathrm{~nm}$. Of the four structural proteins encoded in the viral genome, the RNA winds around the highly basic nucleocapsid $(\mathrm{N})$ protein. The three other structural proteins, envelope $(\mathrm{E})$, membrane (M) and spike (S), are transmembrane proteins. The E protein is a small (9-12 kDa) single transmembrane domain protein, which enables virus assembly with the M protein, a larger (23-35 kDa) 3TM protein. Coronaviruses are named for the crown-shaped appearance of the virus due to the large (120+kDa) S spike 1TM glycoprotein, which forms extended homotrimers. The spike protein binds to the animal host cell by interacting with specific anchoring proteins, typically proteinases, such as angiotensin-converting enzyme 2 or aminopeptidase $\mathrm{N}$. This binding facilitates viral entry into the cell and the release of the genome. Aside from the four structural proteins, the remainder of the genome encodes accessory or non-structural proteins and includes proteinases to cleave the two encoded polyproteins. The remainder of the genome encodes elements for viral replication, assembly and release, as well as proteins which manipulate the host's innate immune system.
\end{abstract}

\section{Contents}

This is a citation summary for SARS-CoV-2 proteins in the Guide to Pharmacology database (GtoPdb). It exists purely as an adjunct to the database to facilitate the recognition of citations to and from the database by citation analyzers. Readers will almost certainly want to visit the relevant sections of the database which are given here under database links.

GtoPdb is an expert-driven guide to pharmacological targets and the substances that act on them. GtoPdb is a reference work which is most usefully represented as an on-line database. As in any publication this work should be appropriately cited, and the papers it cites should also be recognized. This document provides a citation for the relevant parts of the database, and also provides a reference list for the research cited by those parts.

Please note that the database version for the citations given in GtoPdb are to the most recent preceding version in which the family or its subfamilies and targets were substantially changed. The links below are to the current version. If you need to consult the cited version, rather than the most recent version, please contact the GtoPdb curators.

\section{Database links}

SARS-CoV-2 proteins

http://www.guidetopharmacology.org/GRAC/FamilyDisplayForward?familyld=1034

Targets

SARS-CoV-2 Envelope protein

http://www. guidetopharmacology.org/GRAC/ObjectDisplayForward?objectld=3116

SARS-CoV-2 Main protease

http://www.guidetopharmacology.org/GRAC/ObjectDisplayForward?objectld=3111

SARS-CoV-2 Membrane glycoprotein

http://www. guidetopharmacology.org/GRAC/ObjectDisplayForward?objectld=3117

SARS-CoV-2 Non-structural protein 6

http://www.guidetopharmacology.org/GRAC/ObjectDisplayForward?objectld=3118

SARS-CoV-2 Non-structural protein 8 
http://www. guidetopharmacology.org/GRAC/ObjectDisplayForward?objectld=3120 SARS-CoV-2 Nucleoprotein

http://www.guidetopharmacology.org/GRAC/ObjectDisplayForward?objectld=3121 SARS-CoV-2 Protein 3a

http://www.guidetopharmacology.org/GRAC/ObjectDisplayForward?objectld=3115 SARS-CoV-2 Protein 7a

http://www.guidetopharmacology.org/GRAC/ObjectDisplayForward?objectld=3119 SARS-CoV-2 Protein 9b

http://www.guidetopharmacology.org/GRAC/ObjectDisplayForward? objectld=3122 SARS-CoV-2 Protein non-structural 7b

http://www.guidetopharmacology.org/GRAC/ObjectDisplayForward?objectld=3123 SARS-CoV-2 Replicase polyprotein $1 \mathrm{a}$

http://www.guidetopharmacology.org/GRAC/ObjectDisplayForward?objectld=3124 SARS-CoV-2 Replicase polyprotein 1ab

http://www.guidetopharmacology.org/GRAC/ObjectDisplayForward?objectld=3125 SARS-CoV-2 Spike glycoprotein

http://www.guidetopharmacology.org/GRAC/ObjectDisplayForward?objectld=3114

\section{References}

1. Adedeji AO, Marchand B, Te Velthuis AJ, Snijder EJ, Weiss S, Eoff RL, Singh K and Sarafianos SG. (2012) Mechanism of nucleic acid unwinding by SARS-CoV helicase. PLoS ONE 7: e36521 [PMID:22615777]

2. Agostini ML, Andres EL, Sims AC, Graham RL, Sheahan TP, Lu X, Smith EC, Case JB, Feng JY and Jordan R et al.. (2018) Coronavirus Susceptibility to the Antiviral Remdesivir (GS-5734) Is Mediated by the Viral Polymerase and the Proofreading Exoribonuclease. mBio 9: [PMID:29511076]

3. Ahn DG, Choi JK, Taylor DR and Oh JW. (2012) Biochemical characterization of a recombinant SARS coronavirus nsp12 RNA-dependent RNA polymerase capable of copying viral RNA templates. Arch. Virol. 157: 2095-104 [PMID:22791111]

4. Angelini MM, Akhlaghpour M, Neuman BW and Buchmeier MJ. (2013) Severe acute respiratory syndrome coronavirus nonstructural proteins 3,4 , and 6 induce double-membrane vesicles. $m$ Bio 4: [PMID:23943763]

5. Bouvet M, Debarnot C, Imbert I, Selisko B, Snijder EJ, Canard B and Decroly E. (2010) In vitro reconstitution of SARS-coronavirus mRNA cap methylation. PLoS Pathog. 6: e1000863 [PMID:20421945]

6. Bouvet M, Imbert I, Subissi L, Gluais L, Canard B and Decroly E. (2012) RNA 3'-end mismatch excision by the severe acute respiratory syndrome coronavirus nonstructural protein nsp10/nsp14 exoribonuclease complex. Proc. Natl. Acad. Sci. U.S.A. 109: 9372-7 [PMID:22635272]

7. Chen IY, Moriyama M, Chang MF and Ichinohe T. (2019) Severe Acute Respiratory Syndrome Coronavirus Viroporin 3a Activates the NLRP3 Inflammasome. Front Microbiol 10: 50 [PMID:30761102]

8. Cornillez-Ty CT, Liao L, Yates 3rd JR, Kuhn P and Buchmeier MJ. (2009) Severe acute respiratory syndrome coronavirus nonstructural protein 2 interacts with a host protein complex involved in mitochondrial biogenesis and intracellular signaling. J. Virol. 83: 10314-8 [PMID:19640993]

9. Cottam EM, Whelband MC and Wileman T. (2014) Coronavirus NSP6 restricts autophagosome expansion. Autophagy 10: 1426-41 [PMID:24991833]

10. Denison MR, Graham RL, Donaldson EF, Eckerle LD and Baric RS. (2011) Coronaviruses: an RNA proofreading machine regulates replication fidelity and diversity. RNA Biol 8: 270-9 [PMID:21593585]

11. Dong S, Sun J, Mao Z, Wang L, Lu YL and Li J. (2020) A guideline for homology modeling of the proteins from newly discovered betacoronavirus, 2019 novel coronavirus (2019-nCoV). J. Med. Virol. [PMID:32181901]

12. Fan H, Ooi A, Tan YW, Wang S, Fang S, Liu DX and Lescar J. (2005) The nucleocapsid protein of coronavirus infectious bronchitis virus: crystal structure of its $\mathrm{N}$-terminal domain and multimerization properties. Structure 13: 1859-68 [PMID:16338414]

13. Gordon DE, Jang GM, Bouhaddou M, Xu J, Obernier K, O'Meara MJ, Guo JZ, Swaney DL, Tummino TA and Huettenhain R et al.. (2020) A SARS-CoV-2-Human Protein-Protein Interaction Map Reveals Drug Targets and Potential Drug-Repurposing BioRxiv

14. Hilgenfeld R. (2014) From SARS to MERS: crystallographic studies on coronaviral proteases enable antiviral drug design. FEBS J. 281: 4085-96 [PMID:25039866]

15. Imbert I, Guillemot JC, Bourhis JM, Bussetta C, Coutard B, Egloff MP, Ferron F, Gorbalenya AE and Canard B. (2006) A second, non-canonical RNA-dependent RNA polymerase in SARS coronavirus. EMBO J. 25: 4933-42 [PMID:17024178]

16. Jin Z, Du X, Xu Y, Deng Y, Liu M, Zhang B, Li X, Zhang L, Peng C and Duan Y. (2020) Structure of Mpro from COVID-19 virus and discovery of its inhibitors bioRxiv

17. Kim SS, Sze L, Liu C and Lam KP. (2019) The stress granule protein G3BP1 binds viral dsRNA and RIG-I to enhance interferon- $\beta$ response. J. Biol. Chem. 294: 6430-6438 [PMID:30804210] 
18. Lan J, Ge J, Yu J, Shan S, Zhou H, Fan S, Zhang Q, Shi X, Wang Q and Zhang let al.. (2020) Structure of the SARS-CoV-2 spike receptor-binding domain bound to the ACE2 receptor. Nature [PMID:32225176]

19. Law PTW, Wong CH, Au TCC, Chuck CP, Kong SK, Chan PKS, To KF, Lo AWI, Chan JYW and Suen YK et al.. (2005) The 3a protein of severe acute respiratory syndrome-associated coronavirus induces apoptosis in Vero E6 cells. J. Gen. Virol. 86: 1921-1930 [PMID:15958670]

20. Liu ZS, Cai H, Xue W, Wang M, Xia T, Li WJ, Xing JQ, Zhao M, Huang YJ and Chen Set al.. (2019) G3BP1 promotes DNA binding and activation of cGAS. Nat. Immunol. 20: 18-28 [PMID:30510222]

21. Lokugamage KG, Narayanan K, Huang C and Makino S. (2012) Severe acute respiratory syndrome coronavirus protein nsp1 is a novel eukaryotic translation inhibitor that represses multiple steps of translation initiation. J. Virol. 86: 13598-608 [PMID:23035226]

22. Lu W, Zheng BJ, Xu K, Schwarz W, Du L, Wong CK, Chen J, Duan S, Deubel V and Sun B. (2006) Severe acute respiratory syndrome-associated coronavirus 3a protein forms an ion channel and modulates virus release. Proc. Natl. Acad. Sci. U.S.A. 103: 12540-5 [PMID:16894145]

23. Miknis ZJ, Donaldson EF, Umland TC, Rimmer RA, Baric RS and Schultz LW. (2009) Severe acute respiratory syndrome coronavirus nsp9 dimerization is essential for efficient viral growth. J. Virol. 83: 300718 [PMID:19153232]

24. Minakshi R, Padhan K, Rani M, Khan N, Ahmad F and Jameel S. (2009) The SARS Coronavirus 3a protein causes endoplasmic reticulum stress and induces ligand-independent downregulation of the type 1 interferon receptor. PLoS ONE 4: e8342 [PMID:20020050]

25. Minskaia E, Hertzig T, Gorbalenya AE, Campanacci V, Cambillau C, Canard B and Ziebuhr J. (2006) Discovery of an RNA virus 3'->5' exoribonuclease that is critically involved in coronavirus RNA synthesis. Proc. Natl. Acad. Sci. U.S.A. 103: 5108-13 [PMID:16549795]

26. Nakagawa K, Narayanan K, Wada M and Makino S. (2018) Inhibition of Stress Granule Formation by Middle East Respiratory Syndrome Coronavirus 4a Accessory Protein Facilitates Viral Translation, Leading to Efficient Virus Replication. J. Virol. 92: [PMID:30068649]

27. Nelson CA, Pekosz A, Lee CA, Diamond MS and Fremont DH. (2005) Structure and intracellular targeting of the SARS-coronavirus Orf7a accessory protein. Structure 13: 75-85 [PMID:15642263]

28. Nieto-Torres JL, Verdiá-Báguena C, Jimenez-Guardeño JM, Regla-Nava JA, Castaño-Rodriguez C, Fernandez-Delgado R, Torres J, Aguilella VM and Enjuanes L. (2015) Severe acute respiratory syndrome coronavirus E protein transports calcium ions and activates the NLRP3 inflammasome. Virology 485: 3309 [PMID:26331680]

29. Pervushin K, Tan E, Parthasarathy K, Lin X, Jiang FL, Yu D, Vararattanavech A, Soong TW, Liu DX and Torres J. (2009) Structure and inhibition of the SARS coronavirus envelope protein ion channel. PLoS Pathog. 5: e1000511 [PMID:19593379]

30. Pfefferle S, Krähling V, Ditt V, Grywna K, Mühlberger E and Drosten C. (2009) Reverse genetic characterization of the natural genomic deletion in SARS-Coronavirus strain Frankfurt-1 open reading frame $7 \mathrm{~b}$ reveals an attenuating function of the $7 \mathrm{~b}$ protein in-vitro and in-vivo. Virol. J. 6: 131 [PMID:19698190]

31. Pillaiyar T, Manickam M, Namasivayam V, Hayashi Y and Jung SH. (2016) An Overview of Severe Acute Respiratory Syndrome-Coronavirus (SARS-CoV) 3CL Protease Inhibitors: Peptidomimetics and Small Molecule Chemotherapy. J. Med. Chem. 59: 6595-628 [PMID:26878082]

32. Ruch TR and Machamer CE. (2012) The coronavirus E protein: assembly and beyond. Viruses 4: $363-82$ [PMID:22590676]

33. Saikatendu KS, Joseph JS, Subramanian V, Clayton T, Griffith M, Moy K, Velasquez J, Neuman BW, Buchmeier MJ and Stevens RC et al.. (2005) Structural basis of severe acute respiratory syndrome coronavirus ADP-ribose-1"-phosphate dephosphorylation by a conserved domain of nsP3. Structure 13: 1665-75 [PMID:16271890]

34. Shi CS, Qi HY, Boularan C, Huang NN, Abu-Asab M, Shelhamer JH and Kehrl JH. (2014) SARScoronavirus open reading frame-9b suppresses innate immunity by targeting mitochondria and the MAVS/TRAF3/TRAF6 signalosome. J. Immunol. 193: 3080-9 [PMID:25135833]

35. Smith EC, Blanc H, Surdel MC, Vignuzzi M and Denison MR. (2013) Coronaviruses lacking exoribonuclease activity are susceptible to lethal mutagenesis: evidence for proofreading and potential therapeutics. PLoS Pathog. 9: e1003565 [PMID:23966862]

36. Surya W, Li Y, Verdià-Bàguena C, Aguilella VM and Torres J. (2015) MERS coronavirus envelope protein has a single transmembrane domain that forms pentameric ion channels. Virus Res. 201: 61-6 [PMID:25733052]

37. Tan YJ, Fielding BC, Goh PY, Shen S, Tan TH, Lim SG and Hong W. (2004) Overexpression of 7a, a protein specifically encoded by the severe acute respiratory syndrome coronavirus, induces apoptosis via a caspase-dependent pathway. J. Virol. 78: 14043-7 [PMID:15564512]

38. Tanner JA, Watt RM, Chai YB, Lu LY, Lin MC, Peiris JS, Poon LL, Kung HF and Huang JD. (2003) The severe acute respiratory syndrome (SARS) coronavirus NTPase/helicase belongs to a distinct class of $5^{\prime}$ to 3' viral helicases. J. Biol. Chem. 278: 39578-82 [PMID:12917423]

39. te Velthuis AJ, van den Worm SH and Snijder EJ. (2012) The SARS-coronavirus nsp7+nsp8 complex is a unique multimeric RNA polymerase capable of both de novo initiation and primer extension. Nucleic Acids 
Res. 40: 1737-47 [PMID:22039154]

40. ter Meulen J, van den Brink EN, Poon LL, Marissen WE, Leung CS, Cox F, Cheung CY, Bakker AQ, Bogaards JA and van Deventer E et al.. (2006) Human monoclonal antibody combination against SARS coronavirus: synergy and coverage of escape mutants. PLoS Med. 3: e237 [PMID:16796401]

41. Vasilenko N, Moshynskyy I and Zakhartchouk A. (2010) SARS coronavirus protein 7a interacts with human Ap4A-hydrolase. Virol. J. 7: 31 [PMID:20144233]

42. Wang Q, Zhang Y, Wu L, Niu S, Song C, Zhang Z, Lu G, Qiao C, Hu Y and Yuen KYet al.. (2020) Structural and Functional Basis of SARS-CoV-2 Entry by Using Human ACE2. Cell [PMID:32275855]

43. Wilson L, McKinlay C, Gage P and Ewart G. (2004) SARS coronavirus E protein forms cation-selective ion channels. Virology 330: 322-31 [PMID:15527857]

44. Wiser C, Kim B and Ascano M. (2019) G3BP1 enhances cytoplasmic DNA pattern recognition.Nat. Immunol. 20: 5-7 [PMID:30538338]

45. Xu K, Zheng BJ, Zeng R, Lu W, Lin YP, Xue L, Li L, Yang LL, Xu C and Dai £t al.. (2009) Severe acute respiratory syndrome coronavirus accessory protein $9 \mathrm{~b}$ is a virion-associated protein. Virology 388: 279-85 [PMID:19394665]

46. Yan R, Zhang Y, Li Y, Xia L, Guo Y and Zhou Q. (2020) Structural basis for the recognition of SARS-CoV2 by full-length human ACE2. Science 367: 1444-1448 [PMID:32132184]

47. Yang W, Ru Y, Ren J, Bai J, Wei J, Fu S, Liu X, Li D and Zheng H. (2019) G3BP1 inhibits RNA virus replication by positively regulating RIG-I-mediated cellular antiviral response. Cell Death Dis 10: 946 [PMID:31827077]

48. Yuan M, Wu NC, Zhu X, Lee CD, So RTY, Lv H, Mok CKP and Wilson IA. (2020) A highly conserved cryptic epitope in the receptor-binding domains of SARS-CoV-2 and SARS-CoV. Science [PMID:32245784]

49. Zhang L, Li L, Yan L, Ming Z, Jia Z, Lou Z and Rao Z. (2018) Structural and Biochemical Characterization of Endoribonuclease Nsp15 Encoded by Middle East Respiratory Syndrome Coronavirus. J. Virol. 92: [PMID:30135128]

50. Zhang L, Lin D, Kusov Y, Nian Y, Ma Q, Wang J, von Brunn A, Leyssen P, Lanko K and Neyts £t al.. (2020) $\alpha$-Ketoamides as Broad-Spectrum Inhibitors of Coronavirus and Enterovirus Replication: StructureBased Design, Synthesis, and Activity Assessment. J. Med. Chem. [PMID:32045235]

51. Zhang L, Lin D, Sun X, Curth U, Drosten C, Sauerhering L, Backer S, Rox K and Hilgenfeld R. (2020) Crystal structure of SARS-CoV-2 main protease provides a basis for design of improved a-ketoamide inhibitors Science

52. Zhang L, Lin D, Sun X, Curth U, Drosten C, Sauerhering L, Becker S, Rox K and Hilgenfeld R. (2020) Crystal structure of SARS-CoV-2 main protease provides a basis for design of improved $\alpha$-ketoamide inhibitors. Science [PMID:32198291]

53. Zhang R, Wang K, Lv W, Yu W, Xie S, Xu K, Schwarz W, Xiong S and Sun B. (2014) The ORF4a protein of human coronavirus $229 \mathrm{E}$ functions as a viroporin that regulates viral production. Biochim. Biophys. Acta 1838: 1088-95 [PMID:23906728] 